\title{
En kvinne i 50-årene med kronisk utmattelsessyndrom, sepsis og hyponatremi
}

\author{
En kvinne som hadde hatt kronisk utmattelsessyndrom/myalgisk ence- \\ falopati (CFS/ME) i nesten ti år, ble innlagt i sykehus på grunn av pneu- \\ moni med sepsis. Under innleggelsen utviklet hun hyponatremi, og det \\ ble avdekket en annen underliggende diagnose.
}

En kvinne i 50-årene ble funnet hjemme av sin ektemann - som ikke fikk kontakt med henne. Hun hadde hostet og følt seg slapp og uvel de siste dagene. Kvinnen brukte ingen faste legemidler. Da ambulansepersonalet kom frem, var hun desorientert, med en GCS-skår på 13 (Glasgow Coma Scale). Temperaturen var $40,5^{\circ} \mathrm{C}$. Hun fikk $500 \mathrm{ml}$ Ringer-acetat intravenøst på vei til akuttmottaket.

I akuttmottaket kunne hun bevege ekstremitetene, hun var smertefri og ikke nakkestiv. GCS-skåren var uendret. Huden var tørr, varm og uten petekkier. Blodtrykket var lavt $188 / 61 \mathrm{~mm} \mathrm{Hg}-105 / 51 \mathrm{~mm} \mathrm{Hg}-91 / 60$ $\mathrm{mm} \mathrm{Hgl}$ - til tross for infusjon av til sammen $2000 \mathrm{ml}$ Ringer-acetat. Pulsen var regelmessig, mellom 113 og $126 \mathrm{slag} / \mathrm{min}$, temperaturen var $39,7^{\circ} \mathrm{C}, \mathrm{SpO} \mathrm{O}_{2}$ var $97 \%$ med $3 \mathrm{l}$ $\mathrm{O}_{2}$ og respirasjonsfrekvensen lå mellom 20 og 25 per minutt. Ved auskultasjon var det nedsatt respirasjonslyd over høyre lunge, mest uttalt basalt.

Blodprøvene ved innkomst er angitt $i$ tabell 1. Blodgass ble tatt arterielt på romluft. Urinstrimmeltest viste spor av albumin og blod, ellers var det normale funn. Urinpneumokokkhurtigtest var negativ. Røntgen thorax viste en fortetning hilært på høyre side, passende med pneumonisk infiltrat.

Anamnese og kliniske og biokjemiske funn var forenlig med pneumoni med alvorlig sepsis - hun oppfylte tre av fire SIRS-kriterier (systemisk inflammatorisk respons-syndrom) og var i tillegg desorientert. Meningitt/encefalitt var mindre sannsynlig, siden de kliniske funn tydet på luftveisinfeksjon og hun ikke var nakkestiv eller lyssky og ikke hadde hodepine, kvalme eller petekkier.

Det ble gjort en orienterende nevrologiske undersøkelse, uten patologiske funn, men Donders' prøve ble trolig ikke gjennomført.

Det ble startet behandling med penicillin 5 mill. IE $\times 4$ og gentamicin $360 \mathrm{mg} \times 1$ intravenøst. Hun ble flyttet til intensivavdelingen, der hun på grunn av vedvarende lavt blod- trykk til tross for væskebehandling fikk vasopressorbehandling i form av noradrenalin. Hun hadde ikke behov for ventilasjonsstøtte.

Pasienten var omtrent ni år tidligere, etter en øvre luftveisinfeksjon, blitt $100 \%$ sykmeldt på grunn av nautisk svimmelhet, tretthet, slapphet og tidvis nummenhet $i$ armer og ben. Hun hadde også utviklet plager med løs avføring og redusert matlyst, hadde hatt et vekttap på $13 \mathrm{~kg}$, lavt blodtrykk på rundt 100/70 mm Hg (mot tidligere 140/90 $\mathrm{mm} \mathrm{Hg}$ ), hodepine og leddsmerter. nese-hals-lege, øyelege og gastroenterolog, uten at det ble gitt noen sikker diagnose. Gastroskopi med biopsi viste uspesifikke forandringer, koloskopi med biopsi var upåfallende, CT abdomen viste leversteatose Ipasienten drakk på det tidspunktet ca. 10 enheter alkohol per måned), mens MRundersøkelse av tynntarmen ikke viste noe sikkert patologisk. MR caput var normal, og etter nevrologisk vurdering ble det konkludert med dysfunksjon $i$ balansesystemet, mest sannsynlig et sekvele etter influensalignende sykdom. Det ble målt normale verdier for TSH og fritt $T_{4}$. Etter to år med omfattende utredning fikk hun til slutt diagnosen myalgisk encefalopati (ME). Hun ble uføretrygdet og oppga frem til aktuelle innleggelse at hun hadde vedvarende nedsatt livskvalitet.

Dagen etter innleggelsen var pasienten våken, i redusert allmenntilstand, hun hadde vansker med å finne ord og var lett desorientert. Hun hadde fortsatt ingen nakkestivhet, hudutslett eller hodepine. Det ble derfor ikke utført spinalpunksjon. Klinisk undersøkelse var upåfallende, bortsett fra rikelig med krepitasjoner over hele høyre lungeflate. Hun hadde fortsatt tendens til hypotensjon, med systolisk trykk på 90-100 mm Hg, men normal diurese og normalisert nyrefunksjon. Noradrenalin ble trappet ned og seponert og hun ble flyttet til sengepost, der antibiotikabehandlingen ble opprettholdt.

Fire dager etter innkomst ble penicillindosen redusert til 2 mill. IE $\times 4$ intravenøst på grunn av klinisk bedring og fallende infek-
Hun ble vurdert av fastlege, nevrolog, øre-

\section{Kiarash Tazmini}

kiako13@gmail.com

Medisinsk avdeling

Diakonhjemmet Sykehus

og

Oslo universitetssykehus, Ullevål

Torstein R. Meling

Nevrokirurgisk avdeling

Oslo universitetssykehus, Rikshospitalet

Thor Håkon Skattør

Seksjon for radiologi

Oslo universitetssykehus, Rikshospitalet

Øystein Kalsnes Jørstad

$\emptyset$ yeavdelingen

Oslo universitetssykehus, Ullevål

Anders Palmstrøm Jørgensen

Seksjon for spesialisert endokrinologi Oslo universitetssykehus, Rikshospitalet 
sjonsmarkører. Blodkulturer tatt ved innkomst viste ingen oppvekst av mikrober. Dyp neseprøve viste rik vekst av Staphylococcus aureus, vurdert som normalflora. Imidlertid hadde pasienten fallende s-natrium til 121 $\mathrm{mmol} / \mathrm{l}$ (137-145 mmol/l), til tross for infusjon av til sammen 2 l $\mathrm{NaCl} 9 \mathrm{mg} / \mathrm{ml}$. Som ledd $i$ utredning av hyponatremi ble det tatt en rekke laboratorieprøver, vist i tabell 2 , men svarene forelå først etter utskrivning.

Hun utviklet altså alvorlig hyponatremi etter innkomst. Pasienter med pneumoni kan utvikle hyponatremi på grunn av syndrom med uhensiktsmessig sekresjon av antidiuretisk hormon (SIADH). Ved denne tilstanden fører økt sekresjon av antidiuretisk hormon $(\mathrm{ADH})$ til økt reabsorpsjon av vann i nyrene og dermed til hyponatremi. Disse pasientene har ikke behov for væskebehandling med mindre de er hypovoleme, og behandling av pneumonien vil vanligvis korrigere hyponatremien.

Hypotensjon bidrar til hyponatremi gjennom økt ADH-sekresjon fra hypofysen. Uttalt hypotyreose kan også gi hyponatremi via SIADH-fenomenet. Hypotensjon og hyponatremi bør vekke mistanke om binyrebarksvikt (1). Likeledes bør binyrebarksvikt være en differensialdiagnose hos pasienter med uforklarlig eller refraktær hypotensjon som er væske- og vasopressorkrevende (2).

Seks dager etter innkomst ble kvinnen utskrevet i relativt god allmenntilstand. Hun ble behandlet videre med fenoksymetylpenicillin $660 \mathrm{mg} \times 4$ og kaliumklorid $750 \mathrm{mg} \times 3$. Blodprøver viste nå CRP $69 \mathrm{mg} / \mathrm{l}(0-4 \mathrm{mg} / \mathrm{ll}$, leukocytter $4,4 \cdot 10^{9} / \mathrm{l}\left(3,5-10 \cdot 10^{9} / \mathrm{l}\right)$, natrium $131 \mathrm{mmol} / \mathrm{l}$ (137-145 mmol/l), kalium 3,2 $\mathrm{mmol} / \mathrm{l}(3,6-5,0 \mathrm{mmol} / \mathrm{ll})$, kreatinin $47 \mu \mathrm{mol} / \mathrm{l}$ (45-90 $\mathrm{\mu mol} / \mathrm{l})$.

Thyreoideaprøver - TSH 0,78 mIE/l 10,5-3,6 mIE/l) og fritt $T_{4}: 4,5 \mathrm{pmol} / \mathrm{l}(6-20 \mathrm{pmol} / \mathrm{ll})$ førte til at tilstanden ble oppfattet som hypotyreose. Det ble startet med levotyroksin 25 $\mu g \times 1$, en dose som etter en uke ble doblet hos fastlegen. Det ble avtalt oppfølging ved «elektrolyttpoliklikken» ved sykehuset.

Pasientens hypokalemi ved utskrivning kunne ha forskjellige årsaker. Hun var behandlet med noradrenalin og salbutamol, som begge kan føre til forflytning av kalium inn i cellene. Høydose penicillin i tillegg til gentamicin kan føre til nefrogent tap av kalium. Serum-magnesium ble målt dagen etter innkomst, og var på $0,63 \mathrm{mmol} / 1$ (0,71-0,94 mmol/l). Hypomagnesemi kan redusere den tubulære reabsorpsjonen av kalium og kan ha bidratt til hypokalemien.

Hypotensjon kan ha stimulert reninangiotensin-aldosteron-systemet og bidratt til nefrogent tap av kalium. Det ble riktignok
Tabell 1 Blodprøver ved innkomst

\begin{tabular}{|c|c|c|}
\hline $\begin{array}{l}\text { Prøve } \\
\text { Venøse prøver }\end{array}$ & Verdi & Referanseområde \\
\hline Senkningsreaksjon (mm/t) & 19 & $1-17$ \\
\hline $\mathrm{CRP}(\mathrm{mg} / \mathrm{l})$ & 101 & $0-4$ \\
\hline Leukocytter $\left(\cdot 10^{9} / \mathrm{l}\right)$ & 7,9 & $3,5-10$ \\
\hline Hemoglobin (g/100 ml) & 14,2 & $11,7-15,3$ \\
\hline Trombocytter $\left(\cdot 10^{9} / \mathrm{l}\right)$ & 155 & $145-390$ \\
\hline INR & 1,4 & $0,8-1,2$ \\
\hline Bilirubin $(\mu \mathrm{mol} / \mathrm{l})$ & 7 & $5-25$ \\
\hline Albumin lg/l) & 38 & $36-45$ \\
\hline Aktuell fritt kalsium (mmol/l) & 1,14 & $1,15-1,35$ \\
\hline Natrium (mmol/l) & 135 & $137-145$ \\
\hline Kalium (mmol/l) & 4,2 & $3,6-5,0$ \\
\hline Karbamid (mmol/l) & 5,5 & $3,1-7,9$ \\
\hline Kreatinin $(\mu \mathrm{mol} / \mathrm{l})$ & 118 & $45-90$ \\
\hline eGFR $\left(\mathrm{ml} / \mathrm{min} / 1,73 \mathrm{~m}^{2}\right)$ & 46 & $>60$ \\
\hline Glukose (mmol/l) & 5,7 & $4-6$ \\
\hline
\end{tabular}

\section{Arteriell blodgass}

\begin{tabular}{lll}
$\mathrm{pH}$ & 7,39 & $7,35-7,45$ \\
$\mathrm{pCO}_{2}(\mathrm{kPa})$ & 4,9 & $4,7-6,0$ \\
$\mathrm{pO}_{2}(\mathrm{kPa})$ & 9,5 & $10-14$ \\
Bikarbonat (mmol/l) & 22 & $22-26$ \\
Baseoverskudd $(\mathrm{mmol} / \mathrm{l})$ & -3 & \pm 3 \\
Laktat $(\mathrm{mmol} / \mathrm{l})$ & 0,7 & $0,4-0,8$ \\
\hline
\end{tabular}

målt lavt aldosteronnivå ved innleggelsen, men dette kan forklares av samtidig infusjon av $\mathrm{NaCl} 9 \mathrm{mg} / \mathrm{ml}$ under prøvetakningen. Salt- og væsketilførsel hemmer utskilling av renin, mens lavt kaliumnivå hemmer frigjøring av aldosteron (1). Generelt kan thyreoideaprøver være patologiske ved akutt sykdom - høyt eller lavt nivå TSH/fritt $\mathrm{T}_{4}$. Derfor bør disse prøvene tolkes med forsiktighet og eventuelt gjentas når pasienten er i en stabil fase. Lavt nivå av TSH og fritt $\mathrm{T}_{4}$ bør gi mistanke om patologi i hypofyse/hypothalamus.

Straks svarene på hormonanalysene forelå, ble pasienten oppringt. Hun møtte til ny konsultasjon og var da slapp, sliten og svimmel. De siste fem månedene hadde hun hatt problemer med varierende syn på venstre øye, fortalte hun. Utredning hos øyelege var igangsatt, men det var foreløpig ingen konklusjon. Hun hadde ikke hodepine, kvalme eller salthunger, men følte seg veldig sliten og orket ikke å spise. Væskeinntaket var adekvat.

Ved klinisk undersøkelse var hun orientert for tid, sted og situasjon, men trett. Hun eller munnhule. Vekten var 56,8 kg, kroppsmasseindeksen (BMI) 19,2 kg/m². Resultater av blodtrykksmålinger var: sittende $98 / 50$ $\mathrm{mm} \mathrm{Hg}$, puls 80 regelmessig, stående umiddelbart $88 / 62 \mathrm{~mm} \mathrm{Hg}$, puls 102 regelmessig og stående etter tre minutter $70 / 43 \mathrm{~mm} \mathrm{Hg}$, puls 110 regelmessig. Hun ble da svimmel. Synsfeltsundersøkelse ad modum Donders viste normalt synsfelt for høyre øye og innskrenket synsfelt temporalt for venstre øye.

Blodprøver viste natrium $136 \mathrm{mmol} / \mathrm{l}$ (137-145 mmol/l), kalium 4,8 mmol/l $13,6-5,0$ hadde ingen tegn til hyperpigmentering i hud 
Tabell 2 Laboratorieprøver tatt dag 4 som ledd i utredning av hyponatremi. Pasienten fikk $\mathrm{NaCl}$ $9 \mathrm{mg} / \mathrm{ml}$-infusjon mens prøvene ble tatt

Prøve Verdi Referanseområde

Venøse prøver

\begin{tabular}{|c|c|c|}
\hline Natrium (mmol/l) & 121 & $137-145$ \\
\hline Kalium (mmol/l) & 3,3 & $3,6-5,0$ \\
\hline Glukose (mmol/l) & 5 & $4-6$ \\
\hline Kreatinin $(\mu \mathrm{mol} / \mathrm{l})$ & 41 & $45-90$ \\
\hline Effektiv p-osmolalitet (mmol/kg) & 247 & $281-295$ \\
\hline Kortisol, morgen (nmol/l) & 81 & $138-690$ \\
\hline Kortisol, kveld (nmol/l) & 62 & < 50 \% av målte morgenverdi kl 07-09 \\
\hline ACTH, morgen (pmol/l) & 2,2 & $<10,2$ \\
\hline ACTH, kveld (pmol/l) & $<1,1$ & < 50 \% av målte morgenverdi kl 07-09 \\
\hline Aldosteron (pmol/l) & 53 & Sittende 61-1 068, liggende < 653 \\
\hline Reninaktivitet (nmol/l) & $<0,2$ & $<1,5$ \\
\hline $\mathrm{TSH}(\mathrm{mlE} / \mathrm{l})$ & 0,78 & $0,5-3,6$ \\
\hline Fritt $\mathrm{T}_{4}$ (pmol/l) & 4,5 & $8-21$ \\
\hline \multicolumn{3}{|l|}{ Urinprøver } \\
\hline Urin-natrium (mmol/l) & 163 & $\begin{array}{l}\text { > } 30 \text { ved hyponatremi taler for diuretikabruk, } \\
\text { SIADH, binyrebarksvikt }\end{array}$ \\
\hline Urin-kalium (mmol/l) & 13,1 & $<20$ ved hypokalemi taler for ekstrarenalt tap \\
\hline Urin-kreatinin (mmol/l) & 5,13 & U-kalium/u-kreatinin > 1,5 taler for nefrogent tap \\
\hline Urinosmolalitet (mmol/kg) & 561 & $200-800$ \\
\hline
\end{tabular}

mmol/ll. På mistanke om hypofysesvikt ble det tatt nye hormonanalyser, se tabell 3.

Kliniske funn og laboratoriefunn var forenlig med sekundær binyrebarksvikt. Det ble startet behandling med kortisonacetattabletter - $50 \mathrm{mg}$ morgen og $25 \mathrm{mg}$ etter- middag i tre dager, deretter $25 \mathrm{mg}$ morgen og 12,5 mg ettermiddag. Det ble rekvirert MR-undersøkelse av hypofysen. Kaliumklorid ble seponert da det ble oppnådd normokalemi.

Ved kontroll to uker senere fortalte pa-

Tabell 3 Laboratorieprøver tatt som ledd i utredning av hypofysesvikt

\begin{tabular}{lll} 
Prøve & Verdi & Referanseområde \\
Kortisol, morgen (nmol/l) & 55 & $138-690$ \\
ACTH, morgen (nmol/l) & 1,7 & $<10,2$ \\
Aldosteron (pmol/l) & 1330 & Sittende 61-1 068, liggende $<653$ \\
Reninaktivitet (nmol/l) & 2,8 & $<1,5$ \\
FSH (IU/l) & 1,9 & Postmenopausal $>20$ \\
LH (IU/l) & $<0,6$ & $>15$ \\
Prolaktin (m/U/l & 869 & $50-700$ \\
IGF-1 (nmol/l) & 19,4 & $11-40$ \\
\hline
\end{tabular}

sienten at hun følte seg betydelig bedre. «Jeg er som et nytt menneske.» Svimmelheten var borte, hun hadde god matlyst, sov godt og følte for første gang på mange år at hun hadde et overskudd. Hun hadde ikke lenger ortostatisk blodtrykksfall. Nye blodprøver viste natrium $141 \mathrm{mmol} / \mathrm{l} / 137-$ $145 \mathrm{mmol} / \mathrm{l})$, kalium 4,5 mmol/l $(3,6-5,0$ $\mathrm{mmol} / \mathrm{ll})$, kreatinin $52 \mu \mathrm{mol} / \mathrm{l}(45-90 \mu \mathrm{mol} / \mathrm{l})$, karbamid 5,6 mmol/l $(3,1-7,9 \mathrm{mmol} / \mathrm{ll})$, glukose $4,9 \mathrm{mmol} / \mathrm{l}(4-6 \mathrm{mmol} / \mathrm{l}), \mathrm{TSH} \quad 0,21$ $\mathrm{mIE} / \mathrm{l}(0,5-3,6 \mathrm{mIE} / \mathrm{l})$ og fritt $T_{4} 15,3 \mathrm{pmol} / \mathrm{l}$ (8-21 pmol/l).

MR-undersøkelse av hypofysen (fig 1a) viste en stor $(31 \mathrm{~mm} \times 29 \mathrm{~mm} \times 26 \mathrm{~mm}$ ) cystisk intrasellær tumor, med en stor suprasellær komponent som løftet synsnervekrysningen. Funnet ble antatt å representere enten et kraniofaryngeom eller et cystisk hypofysært makroadenom.

Det ble konferert med endokrinolog. Fordi pasienten ikke hadde forhøyet nivå av prolaktin og insulinlignende vekstfaktor-1 (IGF-1) i nedre normalområde, ble hun henvist til nevrokirurgisk behandling.

Ved nevrooftalmologisk vurdering før operasjonen var korrigert skarpsyn 1,6 for høyre øye og 0,25 for venstre øye. Pasienten leste Ishiharas fargeplansjer litt nølende for høyre øye og klarte ingen plansjer for venstre øye. Synsfeltet testet med terskelperimetri (fig 2a) viste en bitemporal reduksjon i sensibilitet, men med overvekt venstre øye. Venstre pupill hadde lett svekket direkte lysrefleks. Ved oftalmoskopi virker venstre synsnerve lett avbleket sammenlignet med høyre, som ved lett optikusatrofi. Nevrologisk status for øvrig var upåfallende.

Hun ble operert med transsfenoidal reseksjon av tumoren i hypofysegropen, med ukomplisert postoperativt forløp.

MR-undersøkelse av hypofysen umiddelbart postoperativt (fig 1b) viste ingen tegn til resttumor, og det var frittliggende synsbaner. Histologisvaret viste at tumoren var et ikkehormonproduserende hypofyseadenom med lavt nivå av proliferasjonsmarkøren ki67.

Ved kontroll tre måneder postoperativt ble det utført synacthentest, som var normal. Behandlingen med kortisonacetat kunne avsluttes. Hun fortsatte med levotyroksin $50 \mu g \times 1$. Funksjonen $i$ veksthormonaksen ble ikke testet, men veksthormonmangel kan ikke utelukkes, selv om IGF-1 lå i normalområdet (3).

Pasienten opplevde rask postoperativ normalisering av synet. Ved kontroll hos øyelege fem måneder etter operasjonen var korrigert skarpsyn 1,25 for begge øynene. Hun leste nå Ishiharas fargeplansjer for begge øynene, men fortsatt lettere for høyre enn for venstre. Terskelperimetri (fig 2b) viste betydelig bedring av tidligere bitemporal reduksjon i sensibilitet. 

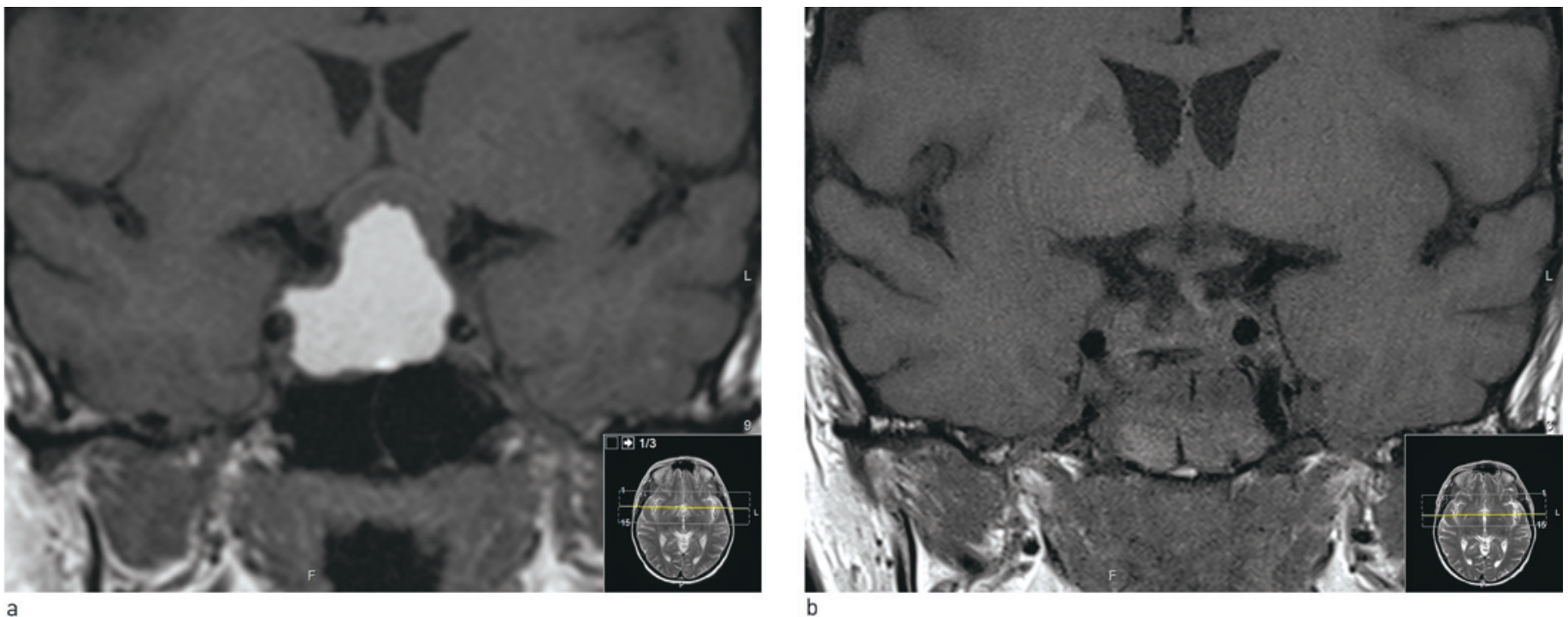

a

Figur 1 Koronale T1-vektede MR-bilder uten kontrast. a) Stor oppfylling i sella turcica som strekker seg opp suprasellært. Synsnervene og synsnervekrysningen er presset oppover og ses som en syltynn halvmåneformet stripe over tumor. Tumor har en solid komponent med lavt signal like under synsbanene. Den større cystiske komponenten ses med høyt signal og tangerer a. carotis interna bilateralt. b) Postoperativ status. Tumor er fjernet transsfenoidalt. Det ligger rikelig med blodprodukter i sinus sphenoidalis. Synsnervene og synsnervekrysningen ligger nå fritt og har fått normalisert tykkelse. Under disse ses hypofysestilken i midtlinjen med lett deviasjon mot venstre (høyre i bildet)

\section{Diskusjon}

Kronisk utmattelsessyndrom/myalgisk encefalopati (CFS/ME) er en sykdom uten sikker og entydig etiologi. I Norge er det angitt at mellom 10000 og 20000 mennesker er rammet, i ulik grad (4). En utløsende årsak til tilstander er infeksjonssykdommer (4), og vår pasient fikk vite at dette var årsaken i hennes tilfelle.

I tillegg til uforklarlig utmattelse, som nedsetter funksjonsnivået betydelig $\mathrm{i}$ forhold til tidligere, har pasienter med denne tilstanden som regel en rekke forskjellige fysiske og kognitive symptomer. Blant disse er ortostatisk hypotensjon, svimmelhet, generell svakhet, muskel- og skjelettsmerter og kvalme (4). Tilsvarende symptomene forekommer også ofte hos pasienter med binyrebarksvikt (5).

Kronisk utmattelsessyndrom/myalgisk encefalopati er en eksklusjonsdiagnose, uten biologiske markører, og den skal først stilles etter grundig anamnese, klinisk undersøkelse og supplerende prøver. Annen fysisk og psykisk sykdom som kan forklare symptombildet må utelukkes, og definerte diagnosekriterier skal benyttes (4).

Blant differensialdiagnosene som må utelukkes er binyrebarksvikt. Dette kan gjøres ved å måle s-kortisol om morgenen - kortisol er blant de anbefalte blodprøvene i Helsedirektoratets veileder (4). Er det fortsatt mistanke om binyrebarksvikt, kan det gjøres testing med syntetisk adrenokortikotropt hormon (ACTH). Ved sekundær (hypofysebetinget) binyrebarksvikt kan testen brukes om det har vært svikt i mer enn omtrent seks uker. Tradisjonelt har kortisolstigning til mindre enn $500 \mathrm{nmol} / \mathrm{l}$ etter 30 minutter vært oppfattet som patologisk. Med nye spesifikke immuntester for kortisol vil normalgrensen ligge lavere (1). Testen utføres tradisjonelt med suprafysiologiske doser syntetisk ACTH $(250 \mu \mathrm{g})$, som ved partiell binyrebarksvikt kan gi falskt positivt svar (6).

Studier indikerer dysfunksjon i hypothalamus-hypofyse-binyrebark-aksen, med blant annet reduksjon i kortisolnivå, hos pasienter med kronisk utmattelsessyndrom/myalgisk encefalopati. Kognitiv behandling kan øke nivået av kortisol og anses som førstelinjeterapi for pasienter med tilstanden. Behandling med kortikosteroider er imidlertid ikke anbefalt for disse pasientene (7-9).

I en norsk retrospektiv studie hvor 365 pasienter med spørsmål om kronisk utmattelsessyndrom/myalgisk encefalopati ble vurdert av nevrolog, fikk 48 (13,2\%) diagnosen og én fikk påvist binyrebarksvikt (10).

Hypofyseadenomer er benigne neoplasmer med en insidens på ca. 4,0 per 100000 per år (11). Adenomer på under $10 \mathrm{~mm}$ kalles mikroadenomer, de over $10 \mathrm{~mm}$ kalles makroadenomer. Av alle påviste makroadenomer er $80 \%$ ikke-hormonproduserende. Hypofysesvikt hos pasienter med makroadenomer kan forårsakes av avklemming av hypofysestilken, kompresjon av hormonproduserende vev i hypofysen eller affeksjon av hypothalamus $(12,13)$.
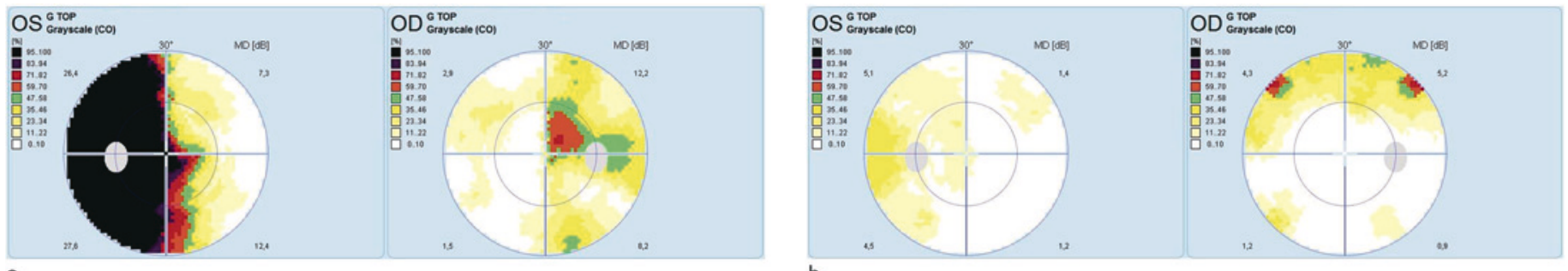

Figur 2 Terskelperimetri for høyre og venstre øye tatt før og etter operasjonen. Fargeskalaen angir prosentvis avvik fra det normale. «Mean deviation» (MD) angir reduksjon i sensibilitet (målt i dB) i de fire synsfeltskvadrantene. a) Før operasjonen var det en bitemporal reduksjon i sensibilitet, men med overvekt venstre øye. b) Etter operasjonen var det en betydelig bedring av prestasjonene 


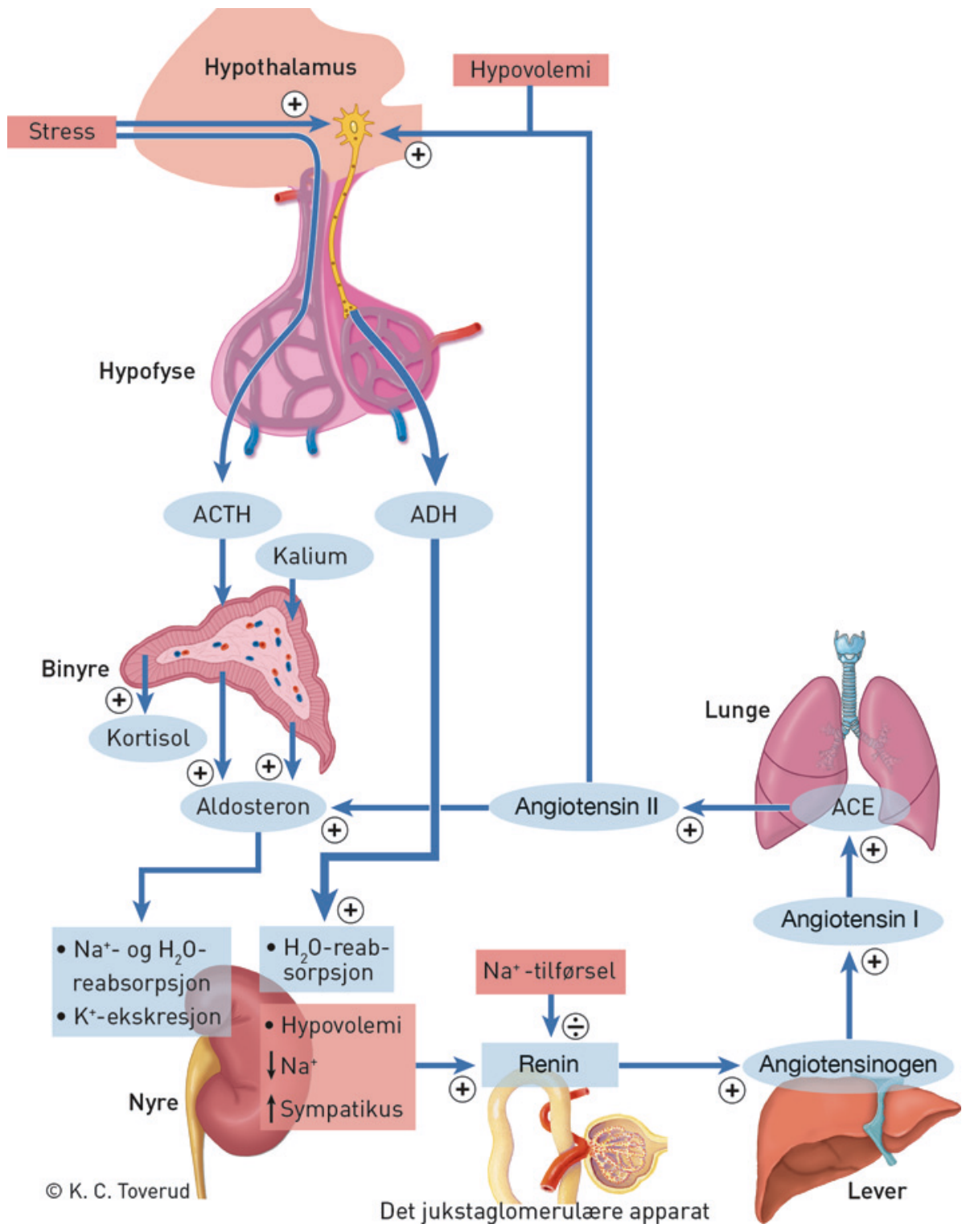

Figur 3 De viktigste mekanismene for regulering av vann-og saltbalansen. Volum blir prioritert fremfor osmolalitet og forklarer tendensen til lavt natriumnivå ved hypovolemi

Ikke-hormonproduserende hypofyseadenomer påvises oftest som et tilfeldig funn, et såkalt incidentalom, ved MR/CT-undersøkelse av hodet, men kan også debutere med synstap eller hypofysesvikt. Hodepine forekommer hos $40-60 \%$ av pasientene og kan skyldes strekk på hjernehinnene og en sjelden gang økt intrakranialt trykk $(12,13)$. Vår pasient hadde stadig hodepine, synstap og en alvorlig hypofysesvikt med lave nivåer av ACTH, TSH og gonadotropiner.

Hypofyseadenomer vokser ofte langsomt. MR-undersøkelsen av hodet var beskrevet som normal den gang hun fikk diagnosen kronisk utmattelsessyndrom/myalgisk encefalopati, og det er derfor sannsynlig at hypofyseadenomet har utviklet seg under for- usikkert hvor lenge hun hadde hyponatremi. Figur 3 illustrerer mekanismene for regulering av vann- og saltbalansen.

Sekundær binyrebarksvikt kan utelukkes dersom s-kortisol i en morgenprøve ligger ved øvre referansegrense. Ved tvil kan det suppleres med synacthentest eller insulintoleransetest, som også tester funksjon i veksthormonaksen. Synacthentest kan ved partiell svikt gi falskt positiv respons, men foretrekkes av mange fordi den har få kontraindikasjoner og er enkel å gjennomføre. Sentral hypotyreose må alltid mistenkes ved lav nivå av fritt $\mathrm{T}_{4}$ og lavt eller normalt TSHnivå (13). Hos vår pasient kan dette ha vært oversett før den aktuelle innleggelsen. Det ble ikke målt s-kortisol som ledd i utredningen av kronisk utmattelsessyndrom/myalgisk encefalopati.

Bildediagnostikk av hypofyseadenomer gjøres med spesialtilpasset MR-undersøkelse. Det gis kontrast og benyttes høyoppløselige serier over hypofysen i koronalplan og sagittalplan som fremstiller tumors relasjon til chiasma og andre viktige omkringliggende strukturer. Der MR-undersøkelse er kontraindisert, vil CT-undersøkelse være et alternativ. Synsfunksjonen skal vurderes av øyelege der man mistenker at hypofyseadenomet påvirker synsnervekrysningen eller andre deler av synsbanene.

Kirurgi er primærbehandlingen hos pasienter med ikke-hormonproduserende makroadenomer. Det er indikasjon for kirurgisk behandling ved redusert synsfunksjon samt ved pituitær apopleksi med påvirket syn eller øyemuskelpareser (øyeblikkelig hjelp-indikasjon). Prolaktinnivået skal måles før inngrepet fordi prolaktinomer nesten alltid skal behandles medikamentelt. Dersom det ikke er klar indikasjon for umiddelbar kirurgisk behandling, bør man også vente på veksthormon- og IGF-1-analysene, fordi data taler for et bedre operasjonsresultat dersom man ved akromegali forbehandler med somatostatin$\operatorname{anlog}(14)$.

Siden sjansene for bedring av en hypofysesvikt bare er marginalt større enn risikoen for forverring av hypofysesvikten ved kirurgi, representerer hypofysesvikt alene ingen sterk indikasjon for kirurgi (15). Transsfenoidal kirurgi med mikroskop og/ eller endoskop er foretrukne operasjonsmetode. Dersom pasienten ikke kan opereres, kan strålebehandling være et alternativ. Hovedmålet med behandlingen er å bevare synsfunksjonen. Kirurgi bedrer synsfunksjonen hos ca. $80 \%$ av pasientene, ofte innen få dager etter inngrepet $(12,13)$. Vår pasient opplevde en subjektiv normalisering av synet og bortfall av hodepinen allerede samme dag hun ble operert.

Mangel på glukokortikoider kan være livstruende, og substitusjonsbehandling må 
startes på klinisk mistanke. Om mulig bør det gjøres hormonanalyser - primært kortisol, $\mathrm{TSH}$, fritt $\mathrm{T}_{4}$ og prolaktin, eventuelt også adrenokortikotropt hormon (ACTH), luteiniserende hormon (LH), follikkelstimulerende hormon (FSH), seksualhormonbindende globulin (SHBG), veksthormon, IGF-1, østradiol (kvinner), testosteron (menn) - før behandlingen igangsettes. Hypotyreose behandles med levotyroksin. Tyroksin øker metabolismen og kan føre til binyrekrise, derfor skal substitusjonsbehandling med tyroksin først gis etter substitusjonsbehandling med glukokortikoid (13). Vår pasient fikk levotyroksin i lav dose i to uker før hun startet med kortisonacetat. Dette kunne ha utløst en binyrekrise. Adekvat hormonsubstitusjonsbehandling kan hos de fleste pasienter nær normalisere livskvaliteten, morbiditeten og mortaliteten assosiert med hypofysesvikten (16).

Ved infeksjoner, feber eller stresstilstander er døgnbehovet av kortison økt. Derfor skal døgndosen økes 2-3 ganger. Ved tegn til binyrebarkkrise skal det gis væske og hydrokortison intravenøst. Etter akuttfasen reduseres dosen raskt til den vanlige vedlikeholdsdosen. Alle pasienter skal utstyres med Norsk steroidkort, som inneholder viktig informasjon til helsepersonell som møter pasienten.

\section{Konklusjon}

Vi har flere formål med å presentere denne kasuistikken. Kronisk utmattelsessyndrom/ myalgisk encefalopati er en eksklusjonsdiagnose, og binyrebarksvikt skal alltid utelukkes før en pasient får diagnosen. Binyrebarksvikt bør vurderes hos pasienter med slapphet/tretthet, svimmelhet/ortostatisme, muskel- og skjelettsmerter eller hyponatremi. Likeledes bør binyrebarksvikt være en differensialdiagnose hos pasienter med uforklarlig eller refraktær hypotensjon som er væske- og vasopressorkrevende. Hypofysesvikt utvikler seg som regel over flere år, og udiagnostisert vil en interkurrent sykdom som for eksempl sepsis kunne føre til binyrebarkkrise og økt mortalitet. Hyponatremi av ukjent årsak, spesielt kronisk eller symptomatisk, bør også utredes med tanke på binyrebarksvikt.
Vår pasient hadde diagnosen kronisk utmattelsessyndrom/myalgisk encefalopati i nesten ti år. Hun ble uføretrygdet og hadde betydelig redusert livskvalitet. Hvor i forløpet hun utviklet hypofysesvikt, vet vi ikke, men en enkel bestemmelse av s-kortisol om morgenen og/eller s-natrium kunne kanskje ha spart henne for mye lidelse.

Pasienten har gitt samtykke til at artikkelen blir publisert.

\section{Kiarash Tazmini (f. 1976)}

er lege i spesialisering og stipendiat. Han har elektrolyttpoliklinikk ved Diakonhjemmet Sykehus

Forfatter har fylt ut ICMJE-skjemaet og oppgir følgende interessekonflikter: Han har mottatt konsulenthonorar fra Otsuka.

\section{Torstein Ragnar Meling (f. 1968)}

er spesialist i nevrokirurgi, professor ved Universitetet i Oslo og seksjonsoverlege.

Forfatter har fylt ut ICMJE-skjemaet og oppgir ingen interessekonflikter.

\section{Thor Håkon Skattør (f. 1979)}

er spesialist i radiologi og overlege.

Forfatter har fylt ut ICMJE-skjemaet og oppgir ingen interessekonflikter.

\section{Øystein Kalsnes Jørstad (f. 1976)}

er spesialist i øyesykdommer og seksjonsoverlege.

Forfatter har fylt ut ICMJE-skjemaet og oppgir ingen interessekonflikter.

\section{Anders Palmstrøm Jørgensen (f. 1965)}

er ph.d., spesialist i indremedisin og i endokrinologi og overlege. Han er leder av Norsk endokrinologisk forening.

Forfatter har fylt ut ICMJE-skjemaet og oppgir ingen interessekonflikter.

\section{Litteratur}

1. Jørgensen AP, Tazmini K. Nasjonal veileder i endokrinologi. 1. utg. Oslo: Norsk endokrinologisk forening, 2015. www.endokrinologi.no (6.1.2017).

2. Reddy P. Clinical approach to adrenal insufficiency in hospitalised patients. Int J Clin Pract 2011; 65: $1059-66$
3. Jørgensen AP, Fougner KJ, Ueland T et al. Favorable long-term effects of growth hormone replacement therapy on quality of life, bone metabolism, body composition and lipid levels in patients with adult-onset growth hormone deficiency. Growth Horm IGF Res 2011; 21: 69-75.

4. Nasjonal veileder. Pasienter med CSF/ME: Utredning, diagnostikk, behandling, rehabilitering, pleie og omsorg. Oslo: Helsedirektoratet, 2015.

5. Bancos I, Hahner S, Tomlinson J et al. Diagnosis and management of adrenal insufficiency. Lancet Diabetes Endocrinol 2015; 3: 216-26.

6. Ospina NS, Al Nofal A, Bancos I et al. ACTH stimulation tests for the diagnosis of adrenal insufficiency: Systematic review and meta-analysis. J Clin Endocrinol Metab 2016; 101: 427-34

7. Papadopoulos AS, Cleare AJ. Hypothalamic-pituitary-adrenal axis dysfunction in chronic fatigue syndrome. Nat Rev Endocrinol 2011; 8: 22-32.

8. Jason LA, Zinn ML, Zinn MA. Myalgic Encephalomyelitis: Symptoms and Biomarkers. Curr Neuropharmacol 2015; 13: 701-34.

9. Smith ME, Haney E, McDonagh M et al. Treatmen of Myalgic Encephalomyelitis/Chronic Fatigue Syndrome: A Systematic Review for a National Institutes of Health Pathways to Prevention Work shop. Ann Intern Med 2015; 162: 841-50

10. Owe J, Næss H, Gjerde IO. Utredning ved mistenk kronisk utmattelsessyndrom/myalgisk encefalopati. Tidsskr Nor Legeforen 2016; 136: 227-32.

11. Raappana A, Koivukangas J, Ebeling T et al. Incidence of pituitary adenomas in Northern Finland in 1992-2007. J Clin Endocrinol Metab 2010; 95: 4268-75.

12. Dekkers OM, Pereira AM, Romijn JA. Treatment and follow-up of clinically nonfunctioning pituitary macroadenomas. J Clin Endocrinol Metab 2008 93: $3717-26$

13. Schneider HJ, Aimaretti G, Kreitschmann-Andermahr I et al. Hypopituitarism. Lancet 2007: 369: $1461-70$

14. Carlsen SM, Lund-Johansen M, Schreiner T et al. Preoperative octreotide treatment in newly diagnosed acromegalic patients with macroadenomas increases cure short-term postoperative rates: a prospective, randomized trial. J Clin Endocrinol Metab 2008; 93: 2984-90.

15. Murad MH, Fernández-Balsells MM, Barwise A et al. Outcomes of surgical treatment for nonfunc tioning pituitary adenomas: a systematic review and meta-analysis. Clin Endocrinol (Oxf) 2010; 73 777-91.

16. Burman P. Mattsson AF, Johannsson $G$ et al. Deaths among adult patients with hypopituitarism: hypocortisolism during acute stress, and de novo malignant brain tumors contribute to an increased mortality. J Clin Endocrinol Metab 2013; 98 : $1466-75$

Mottatt 24.10. 2016, første revisjon innsendt 12.12. 2016, godkjent 6.1. 2017. Redaktør: Kaveh Rashidi. 